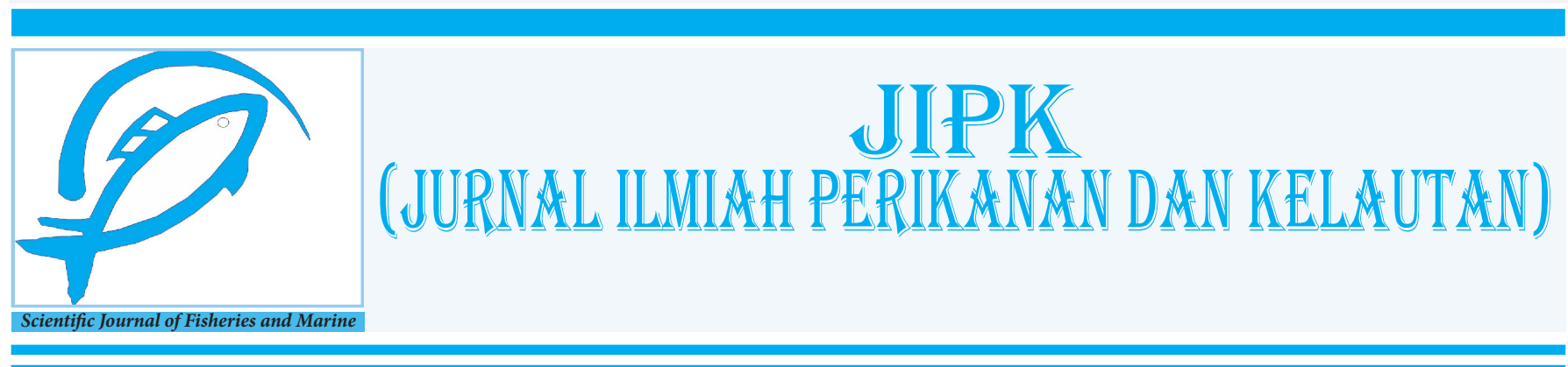

Short Communication

\title{
A Note on Filopaludina martensi martensi (Frauenfeld, 1865) Artificial Breeding Conditions
}

\author{
Kroum Kroumov Hristov* (D) \\ Department of Chemistry and Biochemistry, Medical University, Sofia, 1431. Bulgaria
}

\section{OPEN OCCESS \\ ARTICLE INFO \\ Received: September 25, 2021 \\ Accepted: December 06, 2021 \\ Published: December 10, 2021 \\ *) Corresponding author: \\ E-mail:kkhristov@yahoo.com}

Keywords:

Filopaludina martensi martensi Breeding

Artificial Habitat

This is an open access article under the CC BY-NC-SA license (https://creativecommons.org/ licenses/by-nc-sa/4.0/)

\section{Abstract}

Filopaludina martensi martensi Frauenfeld 1865 is an aquatic Viviparidae gastropod found in Thailand, and throughout Southeast Asia. It is popular in the local cousin, a vector of food-borne trematode infections, and used as a bio-indicator of heavy metal contamination, bio-control agent against Bithynia siamensis Lea 1856, and a way to reduce the total organic matter content from faeces and feed residue during Clarias $s p$. catfish and Nile tilapia aquaculture. The study aims to establish a protocol for breeding $F$. $m$. martensi snails in artificial conditions. The snails were maintained in laboratory conditions. The animals gave birth ( 3 - 4 juveniles) every month. Inflatable, for several hours after the birth, transparent lightly bluish (5 - 6 $\mathrm{mm}$ in diameter) spheres are released in which the fully mature juvenile moves, and leaves several hours later after the sphere breaks. All juveniles studied here die after 2 - 3 months failing to grow into a reproductive adults. F. m. martensi is an attractive animal that regardless of the current difficulties to maintain and grow its juveniles may be popularised in the ornamental fish trade, and a possible laboratory model animal.

Cite this as: Hristov, K. K. (2022). A Note on Filopaludina martensi martensi (Frauenfeld, 1865) Artificial Breeding Conditions. Jurnal Ilmiah Perikanan dan Kelautan, 14(1):167-175. http://doi.org/10.20473/jipk.v14i1.30243 


\section{Introduction}

Filopaludina martensi martensi Frauenfeld 1865 is an aquatic gastropod mollusk in the family of Viviparidae. F. m. martensi is widely used as food in the cuisine of Thailand, and known from papers dealing with pollution (Piyatiratitivorakul and Boonchamoi, 2008) and parasitic disease dissemination, hosting parasites like Paragonimus siamensis, 3 species of Echinostomatidae, and trematode Multicotyle purvisi (Sri-aroon et al., 2007; Köhler et al., 2012; Krailas et al., 2012). Although the infection rate of snails is very low (overall trematode cercariae infection of $1.69 \%$ ), numerous number of the parasite larvae are released (Noikong et al., 2014; Haruay and Piratae, 2019). The need of parasite-free laboratory bred animals for the ornamental fish trade and laboratory model systems serve as the reasons for this work.

F. m. martensi was first described by Eduard von Mertens as Paludina cingulata in 1860 based on specimen collected by Henri Mouhot (Martens, 1860). George Ritter von Frauenfeld named it Paludina martensi (Frauenfeld, 1864). At the moment, 3 species are recognised: Filopaludina martensi martensi Fauenfeld 1864, Filopaludina martensi cambodiensis Brandt 1974, and Filopaludina martensi munensis Brandt 1974.

F. m. martensi is found throughout Southeast Asia; Thailand, Cambodia, Vietnam, Lao People's Democratic Republic, Malaysia, and Indonesia, and is probably present in southern China (Yunnan) and Myanmar. The characteristic habitats are inland freshwaters and permanent wetlands: canals and ponds, and also rivers, streams, and creeks, including waterfalls. It is abundant and plays important roles in the environment (Köhler et al., 2012). Although described as a filter feeder (Piyatiratitivorakul and Boonchamoi, 2008), it is a scraper accumulating pollutants, and can be used as a bio-indicator of heavy metal contamination. Together with Pomacea canaliculata Lamarck 1822, F. $m$. martensi is the most widely distributed mollusk, suggesting its high fitness and good adaptation for new environmental condition (Kwangin et al., 2014). F. m. martensi has been suggested as a bio-control agent against Bithynia siamensis Lea
1856, first intermediate host of the liver fluke Opisthorchis viverrini (Wang et al., 2020). Further, F. m. martensi has been suggested (along with Filopaludina javanica von dem Busch 1844 and Sulcospira testudinaria von dem Busch 1842) as a way to reduce the total organic matter content from organism faeces and feed residue during catfish (Clarias sp.) and Nile tilapia culture (Jiwyam et al., 2008; Lailiyah et al., 2021).

F. m. martensi is found throughout Thailand except in Khong Chiam District, Ubon Ratchathani Province (Sri-aroon et al., 2007). The characteristic habitat is described as evergreen forests (250 - 1350 $\mathrm{m}$ above sea level), medium to large trees allowing filtered sunlight (>10,000 lux at noon), water temperature $22-25^{\circ} \mathrm{C}$, dissolved oxygen $7.1-9.5$ $\mathrm{mg} / \mathrm{L}$, swift current in the rainy season, with smallto medium-sized rocks dispersed across. The snails are found on the rough sand, on aquatic plants, and on the rocks. $7.5 \%$ of the collected (549) aquatic mollusks are $F$. m. martensi, contrasting to $65.4 \%$ Melanoides tuberculata O. F. Muller 1774 (Krailas et al., 2012). In Cambodia, out of the 153 freshwater mollusk 33, including F. m. martensi, are found in Tonle Sap Lake. Accounts for the biodiversity richness of this lake date since $13^{\text {th }}$ century (Zhou Daguan, Chinese diplomat), and later in the 19th and 20th centuries by French-sponsored expeditions (Henri Mouhot, traveller; Auguste Pavie, diplomat; and missionaries like Reeve, Morelet and Morlet). F. m. martensi and F. m. cambodiensis (lacking the spiral ridges) are sold in local markets, but are not harvested in as large quantities as $\mathrm{Me}$ kongia rattei Crosse and P. Fischer 1876 and $\mathrm{Me}$ kongia swainsoni I. Lea 1856, 68 tonnes annually (Ng et al., 2020). F. m. martensi is found as alien introduced species in Singapore, and Israel (since 2005). In Israel it is found along Pomacea maculata Perry 1810, Radix lutuosa Lamarck 1822, Physella gyrina Say 1821, Planorbella duryi Wetherby 1879, Radix luteola Lamarck 1822, and Pomacea diffusa Blume 1957 (Mienis et al., 2015).

F. m. martensi has a gill and an operculum, an ovate-conic shell with $5-6$ convex whorls. The umbilicus is very narrow. The aperture is oblique, ovate and rounded, and cerulean-white in colour (Köhler et al., 2012). Although earlier studies (Bak- 
er, 1928; Thiele, 1929) observe sexual dimorphism in the Viviparidae family snails - the right tentacle of males is modified into a copulatory organ (Brandt, 1974; Tarbsripair, 1998), no clear differences are noted in the F. m. martensi snails. However, F. m. martensi female individuals have larger and heavier shells, with body volume relating to fecundity (Sawangproh et al., 2021). Female viviparid snails bear eggs and embryos $(0$ - 14) inside their brood pouch until they are fully developed (Berry, 1974).

Abiotic and biotic factors influence the distribution and abundance of $F$. m. martensi. In a study (Wang et al., 2020) aimed to evaluate $F$. $m$. martensi as a biological control agent against another freshwater snail - Bithynia siamensis Lea 1856 (the first intermediate host of liver fluke Opisthorchis viverrini), water and soil properties, and snail distribution are studied in Northeast Thailand. While $B$. siamensis has the highest mean dominance in streams and red-yellow podzolic soils, $F$. m. martensi prefers ponds and latosol soils. Both podzolic and latosol soils form under the tropical broadleaf forests (Encyclopedia Britannica, 2016). Red-yellow podzolic soils are of low water holding capacities, low organic matter content and low $\mathrm{pH}$ (Dai et al., 1975). Latosol has a medium drainage and sandy or clayey texture with low pH (Ruivo and Cunha, 2003; Suratno et al., 1998). Further, the bacterial communities play crucial functions in soil ecosystems. Proteobacteria are dominant in forest soils - rich in organic matter and clay, with bacterial cell numbers in the range of $\sim 1.89 \times 10 \mathrm{E} 5 \mathrm{CFU} /$ gdw of forest soil, whereas Firmicutes dominate in the deforestated podzolic areas (Sansupa et al., 2021). The differences observed between biotopes (flora and soil structure), as well as between the river systems (current and sediment load) have been shown to reveal endemism with specific indicator species (Barrios, 2017).

Although the growing number of papers dealing with $F$. m. martensi as an intermediate host of a number of parasites, and an indicator species for environmental pollution, little is known about the basic biology of this widely distributed in Southeast Asia snail. The birth and the growth of juveniles are described, and the reasons for the inability to grow them to reproductive adults are discussed. The study aims to establish a protocol for breeding F. m. martensi snails in artificial conditions.

\section{Materials and Methods}

\subsection{Sample Collecting}

F. m. martensi Frauenfeld 1865 snails were obtained from European trader. The snails were maintained in clean laboratory conditions: local tap water with $\mathrm{pH} 7.42$; GH $0.89 \mathrm{meq} / \mathrm{L}$; conductivity $115.4 \mathrm{uS} / \mathrm{cm}$, and $\mathrm{Cl} 0.11 \mathrm{mg} / \mathrm{L}$ (Sofiyska voda Ltd., Sofia, Bulgaria), and general aquarium consumables: Prime, AmGuard, and Stability (SeaChem Laboratories Inc., Madison, USA) according to the manufacturers recommendations at $25^{\circ} \mathrm{C}$ and 12/12hr light/dark cycle with $947 \mathrm{~lm}$, colour $7700 \mathrm{~K}$ light lux illumination (EHEIM Classic LED lights, EHEIM GmbH \& Co. KG, Germany).

\section{Results and Discussion}

F. m. martensi snails studied in the laboratory were obtained from European dealer, with uncertain origin - probably Thailand (Figure 1). They have an ovate-conic shell, which apex is acute, violet-black in colour (2 - 3 whorls, 4 - 5 in the older animals) (Figure 2). The colour of the shell of the animals discussed here is white (white velvet, silk and opaque, matt - not gloss). In the literature (Köhler et al., 2012), the colour of the shell is green or dark brown to blackish, with fine spiral lines on the whorls. The umbilicus of the shell is very narrow. The shell surface is clear and even with black traverse, not spiral lines. There are no fine spiral lines on the shell as in the reference literature. The last whorl is swollen. Shell width $29+/-2 \mathrm{~mm}$, and height $43+/-4 \mathrm{~mm}$. The aperture is oblique, ovate and rounded, cerulean-white in colour with a black lip. The upper part of the aperture is not acute, with length of $22+/-1 \mathrm{~mm}$. The operculum $(15 \times 12 \mathrm{~mm})$ is ovate with concentric lines, brown to black, colour of horn with golden shining. Although Viviparidae snails are recognised as sexually dimorphic (Baker, 1928; Thiele, 1929; Brandt, 1974; Tarbsripair, 1998), F. m. martensi snails studied here are not sexually dimorphic with males having functional tentacles, and a penis as seen in the copulat- 
ing couple (Figure 3). Female individuals are described to have larger and heavier shells, with body volume relating directly to fecundity (Sawangproh et al., 2021).

Female Viviparidae snails bear their eggs and brood the embryos inside a uterine brood pouch until they are fully developed. There are $0-14$ developing juveniles in the brood-pouch of a female. The female gives birth to fully developed juveniles mainly at night (Berry, 1974). The animals studied in the laboratory gave birth regularly, every month or two, to several (3 - 4) juveniles, regardless of the time of the day. Inflatable for several hours after the birth, transparent lightly bluish spheres 5-6 mm in diameter are released in which the fully mature juvenile moves, and leaves several hours later after the sphere breaks (Figure 4). Unfortunately, all juveniles studied here die after 2 - 3 months failing to grow into a reproductive adults (Figure 5).

In order to overcome this problem and establish the proper laboratory conditions for care and breeding F. m. martensi snails, several experimental setups are underway; long-term maintenance at different $\mathrm{pH}(5$ and 8$)$, water hardness, and various food. Local mud sample (a generous gift from Dr. Duangduen Krailas, Department of Biology, Silpakorn

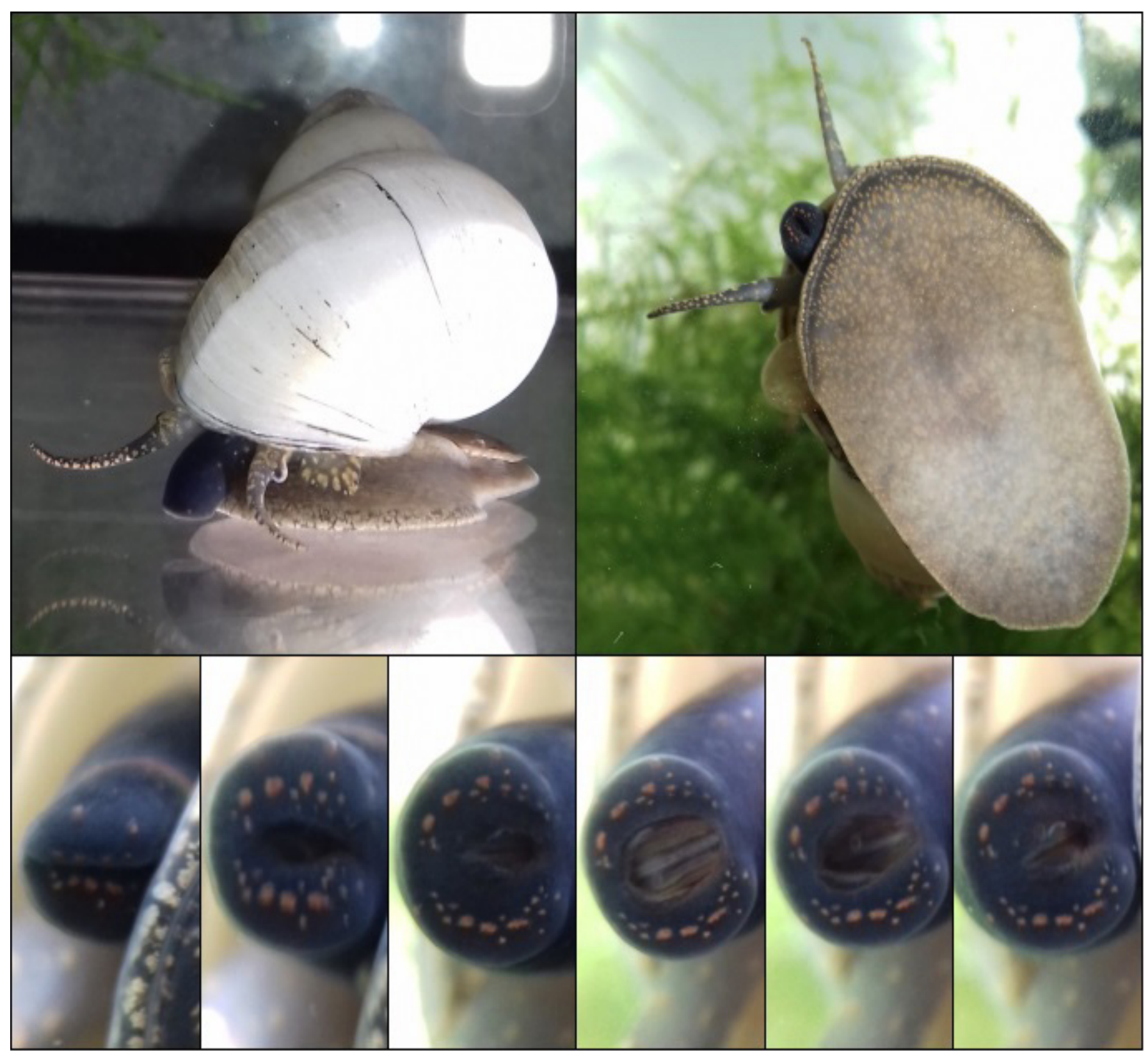

Figure 1. Filopaludina martensi martensi Frauenfeld 1865 


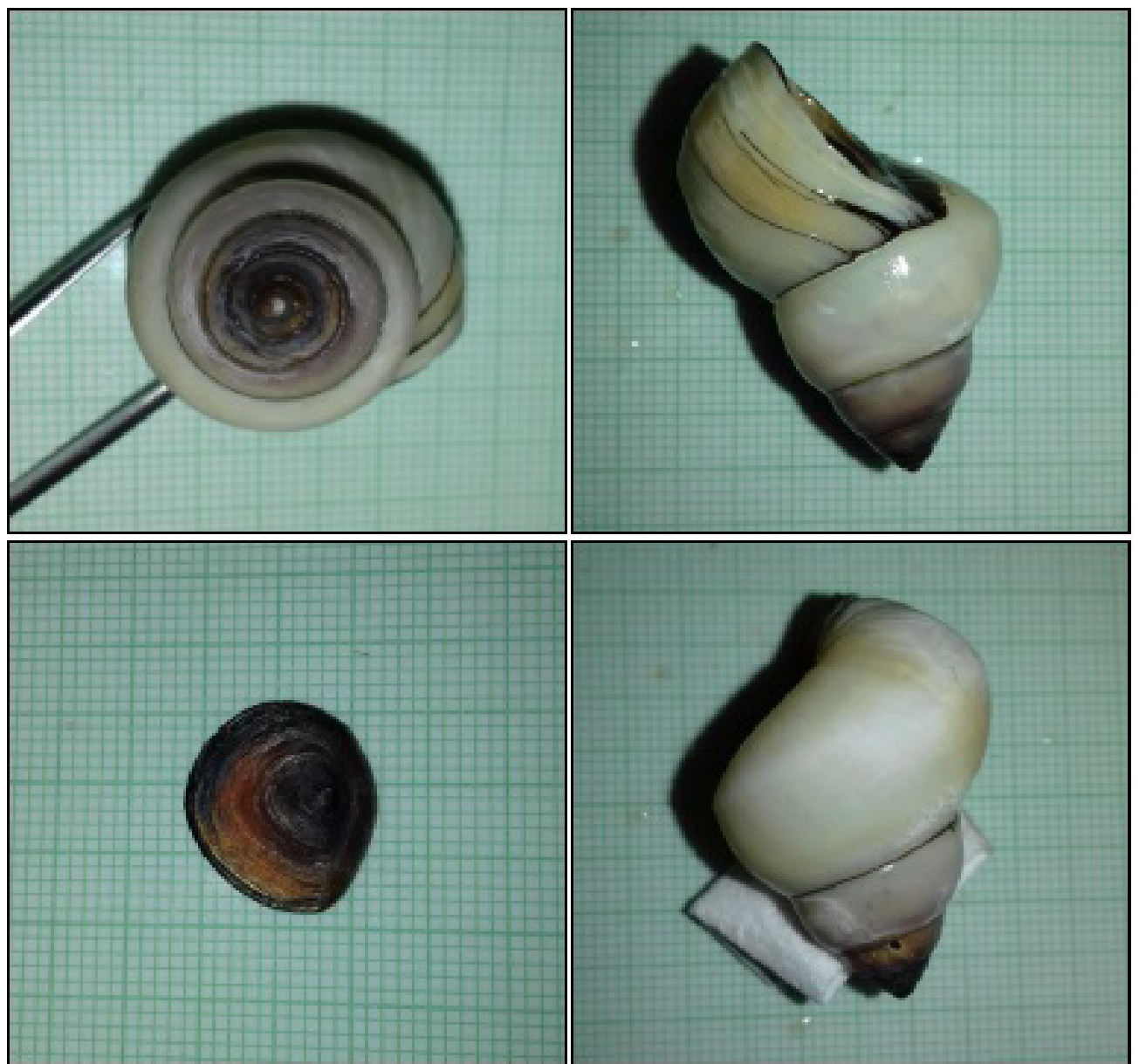

Figure 2. F. m. martensi shell and operculum

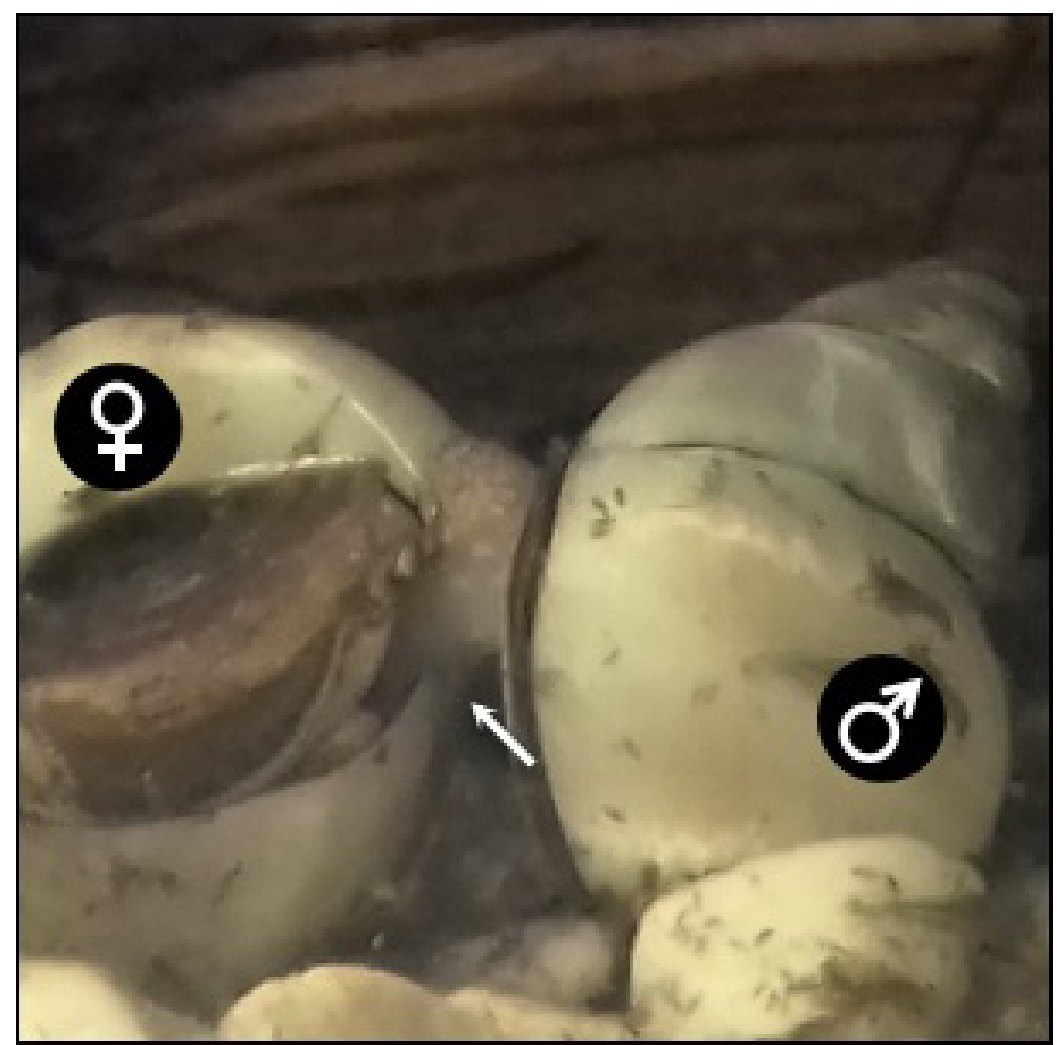

Figure 3. F. m. martensi copulating couple. The penis of the male animal is clearly visible. 
Hristov et al. / JIPK, 14(1):167-175

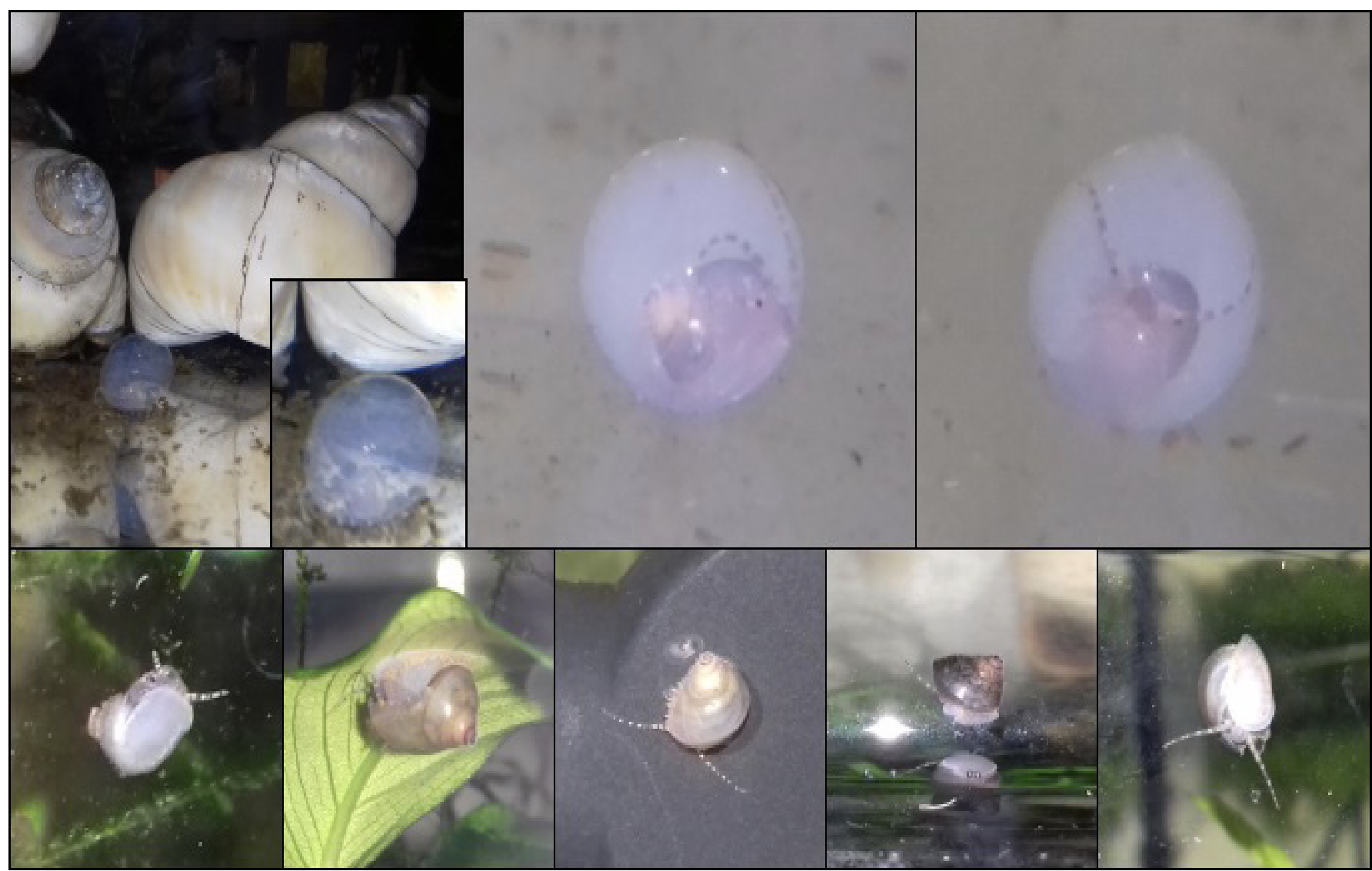

Figure 4. F. m. martensi juveniles. 3-4 juveniles were born regularly, every month or two, regardless of the time of the day. Inflatable (several hours after the birth) transparent lightly bluish spheres 5-6 $\mathrm{mm}$ in diameter are released in which the fully mature juvenile moves, and leaves several hours later after the sphere breaks.

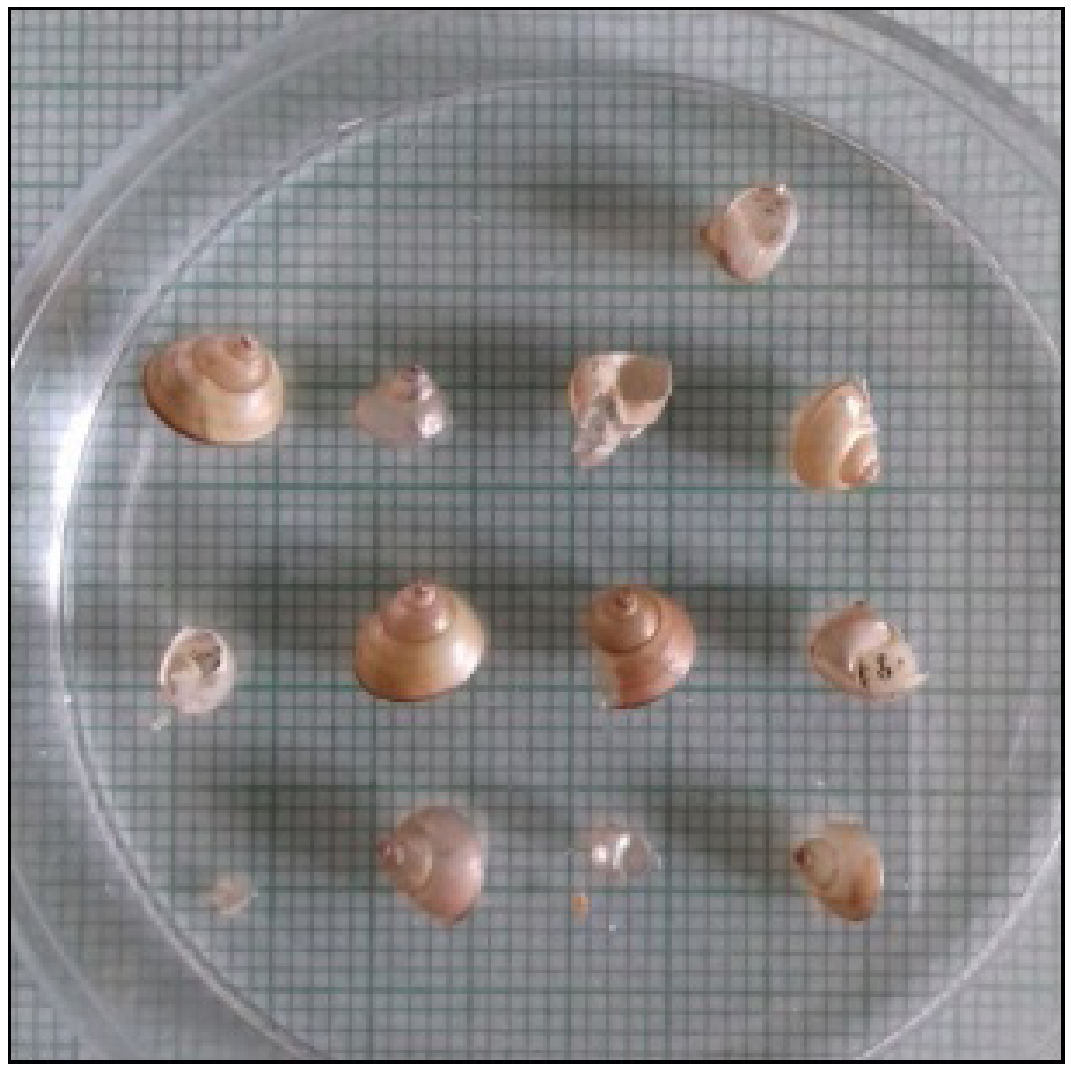

Figure 5. F. m. martensi juvenile shells. 12 shells of the juveniles studied - all die after 2-3 months, fail-ing to grow into a reproductive adults. 
University, Bangkok, Thailand) was obtained in order to investigate the possible algae and microorganisms that could influence the development, growth and survival of the juveniles. Although $F$. m. martensi has a wide distribution range it has a habitat preference for ponds and latosol soils (Wang et al., 2020), constant water quality, water temperature $\left(22-25^{\circ} \mathrm{C}\right)$, and dissolved oxygen $(7.1-$ $9.5 \mathrm{mg} / \mathrm{L})$ (Krailas et al., 2012). Bottom sediment (Nile tilapia aquaculture) and 'green water' (phytoplankton, chlorophyll-a $392.8+/-384.3 \mathrm{ug} / \mathrm{L}$ ) are an important source of nutrients. Interestingly, in this study the temperature $\left(34.8+/-1.9^{\circ} \mathrm{C}\right)$ and $\mathrm{pH}(8.9+/-0.8)$ values are higher (Jiwyam et al., 2008). Similarly, Piyatiratitivorakul and Boonchamoi (2008) maintain F. m. martensi juvenile snails (weight $1-4 \mathrm{~g}$, height $0.7-1.0 \mathrm{~cm}$ and width $0.5-0.7 \mathrm{~cm}$ ) at $22-29^{\circ} \mathrm{C}$ and $\mathrm{pH} 7-9$ with mortality not exceeding $10 \%$. The more acidic environment could be the reason for the inability to maintain and grow the juveniles (Figure 4). An alkaline habitat with a higher GH value (lack of plants), and a convenient biofilm could be the solution of the problem.

The differences observed between biotopes (flora, soil structure and sediment load) have been shown to reveal endemism with specific indicator species (Barrios, 2017). Although F. m. martensi has been shown to have habitat preference, its wide distribution throughout Thailand, and the suggested use as a bio-control agent against $B$. siamensis make it difficult to understand the reason behind the failure to maintain and grow $F$. m. martensi juveniles in artificial habitat. The importance of the differential bacterial load (Proteobacteria / Firmicutes ratio) as suggested by the alteration of the bacterial communities during the process of transformation of clayey latosols into white-sand podzols (Sansupa et al., 2021) will be subject to future investigation.

\section{Conclusion}

Filopaludina martensi martensi Frauenfeld 1865 , a common viviparid snail inhabiting the ponds and the canals in Thailand, and throughout Southeast Asia, can be maintained and reproduce successfully in artificial conditions. Further, the birth and the initial growth of $F$. m. martensi juveniles are observed and described. All juveniles were lost when maintained at $\mathrm{pH} 7.42, \mathrm{GH} 0.89 \mathrm{meq} / \mathrm{L}$, conductivity $115.4 \mathrm{uS} / \mathrm{cm}$, temperature $25^{\circ} \mathrm{C}$ and 12/12 hr light/dark cycle with $947 \mathrm{~lm}$, colour $7700 \mathrm{~K}$ light lux illumination. F. m. martensi is a beautiful animal that may be popularised in the ornamental fish trade, and a possible laboratory model animal. In order to establish the proper laboratory conditions for care and breeding, several experimental setups are underway: long-term maintenance at different $\mathrm{pH}$ and water hardness, and various food. Culture and 16S DNA analysis methods are used to investigate the possible algae and microorganisms that could influence the development, growth, and survival of the juveniles.

\section{Acknowledgement}

The author would like to express his gratitudes to Dr. Duangduen Krailas, Department of Biology, Silpakorn University, Bangkok, Thailand for providing a local mud sample and advice, and Dr. Frank Koehler, Australian Museum Research Institute, Australian Museum, Sydney, Australia for the valuable suggestions.

\section{Authors' Contributions}

The author is the only contributor to the work presented in this manuscript, and to the manuscript itself.

\section{Conflict of Interest}

The author declares that the research was conducted in the absence of any commercial or financial relationships that could be construed as a potential conflict of interest.

\section{Funding Information}

The work presented in this manuscript has been privately funded.

\section{References}

Baker, F. C. (1928). The fresh water Mollusca of Wisconsin, Part 1: Gastropoda. Bulletin of the Wisconsin Geological and Natural History Survey, 70:1- 
507.

Barrios, H. (2017). Arthropods (Terrestrial), Amazonian. In Reference Module in Life Sciences. Amsterdam: Elsevier.

Berry, A. J. (1974). Reproductive condition in two Malayan freshwater viviparid gastropods. Journal of Zoology, 174:357-367.

Brandt, R. A. M. (1974). The non-marine aquatic Mollusca of Thailand. Archiv fur Molluskenkunde, 105:1-423.

Dai, J., Sudihardjo, \& Buurman, P. (1975). Red-yellow podzolic soils from the Lampung and South Sumatra provinces (Sumatra, Indonesia). Paper presented at Proc. 3d ASEAN soil conference, Kuala Lumpur, Malaysia.

Encyclopedia Britannica (2021). Podzolic soil. Retrieved on September 19, 2021 from https:// www.britannica.com/science/podzolic-soil

Frauenfeld, G. V. (1864). Verzeichniss der Namen der fossilen und lebenden Arten der Gattung Paludina Lam. Nebst jenen der nachststehenden und Einreihung derselben in die verschiedenen neueren Gattungen. Verhandlungen der Kaiserlich-Koniglichen Zoologisch-Botanischen Gesellschaft in Wien, 14:561-672.

Haruay, S., \& Piratae, S. (2019). Situation and cercarial infection of freshwater mollusk from Sirindhorn Reservoir, Ubon Ratchathani Province, Thailand. Iranian Journal of Parasitology, 14(3):421-429.

Jiwyam, W., Tippayadara, N., \& Dachrat, P. (2008). A survay of freshwater gastropods in fish ponds and first results of its cage culture integrated with pond culture of Nile tilapia. Paper presented at Conference: International Symposium Sustaining Fish Diversity, Fisheries and Aquacultures in the Mekong Basin, Ubon Ratchathani University, Thailand.

Köhler, F., Sri-aroon, P. \& Simonis, J. (2012). Filopaludina martensi. In The IUCN red list of threatened species 2012 .

Krailas, D., Chotesaengsri, S., Dechruksa, W., Namchote, S., Chuanprasit, C., Veeravechsukij, N., Boonmekam, D., \& Koonchornboon, T. (2012). Species diversity of aquatic mollusks and their cercarial infections; Khao Yai National Park, Thailand. Journal of Tropical Medicine and Parasitology, 35:37-47.

Kwangin, N., Tuntiwaranurak, C., Dumrongrojwattana, P., \& Khachonpisitsak, S. (2014). Species diversity and distribution of freshwater mollusks after waterway dredging in Nongchok Area, Bangkok, Central Thailand. Paper presented at the Burapha University International Conference 2014. Thailand: Burapha University.

Lailiyah, S., Arfiati, D., Hertika, A. M. S., Arum, N. D. K., \& Noviya, C. B. (2021). The effectiveness of Filopaludina javanica and Sulcospira testudinaria in reducing organic matter in catfish (Clarias sp.) aquaculture wastewater. Jurnal Ilmiah Perikanan Dan Kelautan., 13(1):106-113.

Martens, E. V. (1860). On the Mollusca of Siam. Proceedings of the Zoological Society of London, 28:6-18.

Mienis, H. K., Vaisman, S., \& Rittner, O. (2015). A first find of the S.E.-Asian Filopaludina martensi in a pond in a public park in Kefar-Sava, Israel. Ellipsaria, 17(1):25-27.

Ng, T. H., Jeratthitikul, E., Sutcharit, C., Chhuoy, S., Pin, K., Pholyotha, A., Siriwut, W., Srisonchai, R., Hogan, Z. S., \& Ngor, P. B. (2020). Annotated checklist of freshwater mollusks from the largest freshwater lake in Southeast Asia. ZooKeys, 958:107-141.

Noikong, W., Wongsawad, C., Chai, J.-Y., Saenphet, S., \& Trudgett, A. (2014). Molecular analysis of Echinostome metacercariae from their second intermediate host found in a localised geographic region reveals genetic heterogeneity and possible cryptic speciation. PLOS Ne- 
glected Tropical Diseases, 8(4):e2778.

Piyatiratitivorakul, P., \& Boonchamoi, P. (2008). Comparative toxicity of mercury and cadmium to the juvenile freshwater snail, Filopaludina martensi martensi. ScienceAsia, 34:367370 .

Ruivo, M. L., \& Cunha, E. S. (2003). Mineral and organic components in archaeological black earth and yellow latosol in Caxiuana, Amazon, Brazil. Transactions on Ecology and the Environment, 64:1113-1121.

Sansupa, C., Purahong, W., Wubet, T., Tiansawat, P., Pathom-Aree, W., Teaumroong, N., Chantawannakul, P., Buscot, F., Elliott, S., \& Disayathanoowat, T. (2021). Soil bacterial communities and their associated functions for forest restoration on a limestone mine in northern Thailand. PLoS ONE, 16(4):e0248806.

Sawangproh, W., Phaenark, C., Chunchob, S., Paejaroen, P. (2021). Sexual dimorphism and morphomeric analysis of Filopaludina martensi martensi (Gastropoda: Viviparidae). Ruthenica, 31(2):87-92.

Sri-aroon, P., Butraporn, P., Limsoomboon, J., Kaewpoolsri, M., Chusongsang, Y., Charoenjai, P., Chusongsang, P., Numnuan, S. \& Ki atsiri, S. (2007). Freshwater mollusks at designated areas in eleven provinces of Thailand according to the water resource development projects. Southeast Asian Journal of Tropical Medicine and Public Health, 38(2):294-301.

Suratno, W., Murdiyarso, D., Suratmo, F. G., Anas, I., Saeni, M. S., \& Rambe, A. (1998). Nirous oxide flux from irrigated rice fields in West Java. In K. v. d. Hoek, J. W. Erisman, S. Smeulders, \& J. Wisniewski ( $1^{\text {st }}$ Ed.), Nitrogen, the Confer-N-s. (pp. 159-166). Amsterdam: Elsevier.

Tarbsripair, P. (1998). The genus Filopaludina (Proso-branchia Gastropoda) of Thailand: Morphology, Anatomy, Allozymes and Systematic Relationships. Dissertation. Thailand: Mahidol University.

Thiele, J. (1929). Handbuch der systematischen Weichtierkunde. German: Verlag Von Gustav Fischer.

Wang, Y. C., Liew, T. Z., Namsanor, J., \& Sithithaworn. (2020). Assessing the role of Filopaludina martensi martensi as a biocontrol agent of Bothynia siamensis goniomphalos, the first intermediate host of Opisthorchis viverrini. Parasitology Research, 119:3415-3431. 